\title{
AXIOLOGICAL ASPECTS OF TRADITIONAL FAMILY EDUCATION IN THE BELGOROD REGION
}

\author{
ASPECTOS AXIOLÓGICOS DA EDUCAÇÃO FAMILIAR TRADICIONAL NA REGIÃO \\ DA BELGOROD
}

\author{
ASPECTOS AXIOLÓGICOS DE LA EDUCACIÓN FAMILIAR TRADICIONAL EN LA \\ REGIÓN DE BELGOROD
}

\author{
Sergey I. KURGANSKY ${ }^{1}$ \\ Natalia V. BARANICHENKO ${ }^{2}$ \\ Ulia V. BOVKUNOVA ${ }^{3}$ \\ Vitaly V. KISTENEV ${ }^{4}$
}

\begin{abstract}
The article is devoted to the axiological aspects of traditional family education in the Belgorod region. The article analyzes and compares the features of family education in Russia and the Belgorod region and provides a historical overview of the problem. The authors come to the conclusion that the basis of traditional family education in different historical periods was: respect for the elders and showing attention to the younger ones; value attitude to the native language in the family; labor education from an early age, based on the division of responsibilities according to gender; careful attitude to the land; morality, consisting of religion and nationality, using family-household and calendar rites. Multiculturalism inherent in the study area: the interaction of Russian, Polish, Ukrainian, Lithuanian, Belarusian traditions, could not but affect family education, the dynamics of spiritual values of society, values in leisure and cultural institutions of the Belgorod region.
\end{abstract}

KEYWORDS: Family. Values. Belgorod region. Axiology. Education. Multiculturalism.

RESUMO: O artigo é dedicado aos aspectos axiológicos da educação familiar tradicional na região de Belgorod. O artigo analisa e compara as características da educação familiar na Rússia e na região de Belgorod e fornece uma visão geral histórica do problema. Os autores concluem que a base da educação tradicional da família nas diferentes épocas históricas era: o respeito pelos mais velhos e a atenção aos mais novos; atitude de valorização da língua nativa na família; a educação para o trabalho desde a infância, baseada na divisão de responsabilidades de acordo com o gênero; atitude cuidadosa para com a terra; moralidade, consistindo de religião e nacionalidade, usando ritos familiares e de calendário. Multiculturalismo inerente à área de estudo: a interação das tradições russa, polonesa,

\footnotetext{
${ }^{1}$ Belgorod State Institute for Arts and Culture, Belgorod - Russia. Doctor of pedagogical Sciences, professor, rector of Belgorod State Institute for Arts and Culture. Honored Worker of Culture of the Russian Federation. ORCID: https://orcid.org/0000-0003-3600-3839. E-mail: rektor@bgiik.ru

${ }^{2}$ Belgorod State Institute for Arts and Culture, Belgorod - Russia. Candidate of philosophy Sciences. ORCID: https://orcid.org/0000-0002-0442-9248. E-mail: bgiik@bgiik.ru

${ }^{3}$ Belgorod State Institute for Arts and Culture, Belgorod - Russia. Candidate of philosophy Sciences. ORCID: https://orcid.org/0000-0002-1724-4453.E-mail: bgiik@bgiik.ru

${ }^{4}$ Belgorod State Institute for Arts and Culture, Belgorod - Russia. Candidate of historical Sciences, Associate Professor. ORCID: https://orcid.org/0000-0002-6250-033X. E-mail: kisvita@mail.ru
} 
ucraniana, lituana, bielorrussa, não poderia deixar de afetar a educação familiar, a dinâmica dos valores espirituais da sociedade, valores no lazer e instituições culturais da região de Belgorod.

PALAVRAS-CHAVE: Família. Valores. Região de Belgorod. Axiologia. Educação. Multiculturalismo.

RESUMEN: El artículo está dedicado a los aspectos axiológicos de la educación familiar tradicional en la región de Belgorod. El artículo analiza y compara las características de la educación familiar en Rusia y la región de Belgorod, y ofrece una visión histórica del problema. Los autores llegan a la conclusión de que la base de la educación familiar tradicional en diferentes períodos históricos fue: el respeto a los mayores y la atención a los más jóvenes; valorar la actitud hacia la lengua materna en la familia; educación laboral desde temprana edad, basada en la división de responsabilidades por género; actitud cuidadosa hacia la tierra; moralidad, que consiste en religión y nacionalidad, utilizando ritos de familiahogar y calendario. El multiculturalismo inherente al área de estudio: la interacción de las tradiciones rusa, polaca, ucraniana, lituana y bielorrusa no podía dejar de afectar la educación familiar, la dinámica de los valores espirituales de la sociedad, los valores en el ocio y las instituciones culturales de la región de Belgorod.

PALABRAS CLAVE: Familia. Valores. Región de Belgorod. Axiología. Educación. Multiculturalismo.

\section{Introduction}

In traditional culture of the Russian people a particular family pattern with its distinctive feature of oneness and its main task of transformation had been formed throughout the centuries. The existing pattern corresponded not only to the principles inherent in Russian traditional culture but it was also fundamental for the entire society. Family is perceived by us as a repository of the traditions of Russian culture, world outlook of the people and sustainable Russian statehood.

It is from this perspective that the family gives a grounding in traditional family education. For our part, we understand that family education is a conscious effort launched by the older generation and directed towards the younger generation.

Family relevance as a determining factor in the process of upbringing determines its influence on the personal enhancement of a child, including their needs, motivational sphere, attitude towards themselves and towards surrounding persons.

Thus, traditional family education should form mental and emotional foundations of an individual, give a child ideas about life in society, about good and evil, acquaint them with the values that are recognized and used by this family in its daily life, that is, form the basic morals 
and ethical principles. That is why, each individual family is a specific system of social relations, the quality of which determines certain social conditions for child development in the family.

In our research we rely on the works on axiology by R. Lotze, H. Rickert, W. Windelband, C. Ehrenfels and A. Meinong. Theoretical insights in the problem are found in the philosophical works by V. S. Solovyov, N. A. Berdyaev, N. O. Lossky, O. G. Drobnitsky, L. N. Kogan, V. P. Tugarinov; E. Husserl, R. Lotze, M. Scheler, K. Jaspers; psychological perspective is disclosed on the basis of the works by V. G. Aseyev, Y. M. Zabrodin, D. A. Leontyev, V. A. Petrovsky, S. L. Rubinstein, L. Kohlberg, K. Lewin, A. Maslow, A. Meinong, G. Allport, J. Rotter, E. Tolman, E. Spranger, C. Ehrenfels.

In Russia in the 19th century there were patriarchal families and patriarchal relations that presented the national sociocultural tradition. Drawing on the research, we found that there was a notion of idealistic marriage along with the concept of patriarchy. The main idea of marriage was based on Orthodox teaching. From this perspective, family was viewed as a union of a man and a woman where the first place was given to love, expressed in self-sacrifice and raising children in this hypostasis.

Studying this aspect, we have learnt that the concept of "idealistic marriage" is interpreted differently by representatives of different research directions. For example, representative of the Russian Orthodox Church, G. Dyachenko understands this type of marriage as a common name for a married couple in relation to each other (DYACHENKO, 1993). Writer and ethnographer V. Dahl considered idealistic marriage as a relationship between two generations - parents and children, expressed in family happiness.

This is precisely why, according to V. Dahl, family happiness cannot be measured by wealth, talent or health. Family happiness is love, sincerity and harmony in a relationship. Family should be perceived as a home for each family member and should soak up warmth, care, understanding, support, help and mutual assistance (DAHL, 1998).

We have analyzed the main components that more fully reveal the understanding of the family in traditional culture. The family is a sacred union and a natural form of living together. We consider the spiritual and psychological component of traditional family education to be one of the main features. We subsume family unity, holiness, conciliarity, apostolate under the main characteristics.

One should refer not only physical and spiritual unity of a husband and wife, but also the same character, the same value attitudes, a joint choice of life goals to family unity and family education. The formed psychological space of the family is manifested in mutual trust, 
respect, overcoming life's difficulties. Therefore, the unity of family was considered to be the unity of fate.

If there was unity in the family, then holiness reigned in such family, which was evident in the fact that the spouses were to cultivate love, goodness and beauty in their relationship.

The family conciliarity was represented in its hierarchical structure. This meant hierarchy, care, service to each other, when making decisions and obeying a family head. Building relations in such a family was based on the law of voluntary submission to the highest Christian values.

We see family apostleship as another component. This term indicates the maintaining of family traditions that is inherent in Russian traditional culture. Compliance with all four components contributes to family well-being, tranquility and love.

The originality of patriarchal family was studied not only by representatives of the 19th century but of the 20th century as well. So, at the end of the 20th century social anthropologist S. N. Gavrov wrote that the once existing patriarchal family represented a special world of warm human relations. In such a family there was mutual support, maintenance of each other. The family was a microcosm in which each family member made their own contribution to a family business (GAVROV, 2009).

We consider it possible to cite some essential characteristics of the patriarchal family from our perspective. First, such a family was to represent a couple married in church that meant lifelong honesty and loyalty. Second, the family was presented as a small Church existing for joint upbringing of children. This position is borne out in the works by V. V. Zenkovsky (1993). Third, we found out that the family was perceived as a value in itself, the essence of which was the right habits of living. Fourth, a patriarchal family should have an expanded composition and comprehend at least three generations living under one roof. Fifth, from the point of view of a folklorist and researcher of folk culture, A. F. Nekrylova, it was possible to trace the relationship between parents and children in a patriarchal family on the basis of gradual entry of the latter into the family's working life and a ritual constituent of the culture of that period (NEKRYLOVA; SOKOLOVA, 2003). Sixth, in such families there was a strict hierarchy, the domination of a husband and submission to him. Possession of many children was a commonplace and focused on love for children with external emotional restraint. Humility, respect, reverence and identity of the family community were based on national, cultural and spiritual and moral principles.

Speaking about the peculiarities of family education in Russia, it should be noted that the specific features of the Russian people were formed both under the influence of basic values 
(kindness, meekness, collegiality, chastity) and under the influence of geographical and climatic factors. Another aspect that had a significant impact on the formation of Russian nation and identity can be considered the historical features of the formation of state (neighborhood with the Polovtsy, Pechenegs, Scythians, raids of the Golden Horde), folk Orthodoxy (a mixture of Christian traditions and values with popular beliefs, rituals and customs).

As a result, we have a unique system of education based on the relationship between the categories of individual and social mental values. There is no doubt that it was the family that was responsible to society for the quality of parenting. Co-residing of at least three generations, not only upbringing but also education took place. Accepting the opinion of K. D. Ushinsky, it is significant to note that not only mothers and grandmothers, but also nannies, teenage girls were as Russian teachers. Education was the most important function for the older generation (USHINSKY, 2002).

When considering the issues of family education in Russia, we note that the social aspect configured itself in the "text of culture" regulating the way of life of the peasant community, while the cultural one configured itself as a "cultural code" determining the historically established social order.

It is important to emphasize that moral and ethical standards have been changing since the adoption of Christianity. For example, in the literature of the period of Kievan Rus The Sermonizing of Vladimir Monomakh, and in the literary and pedagogical work of the 18th century The Honest Mirror of Youth, one can read a detailed description of educational process. This brings us to the conclusion that the problem of education was raised regardless of the historical period and was universal.

According to the original written sources that was widely used for education of the younger generation, there was the theory of obedience which was spelled out in The Domostroy (The "Household Book"). The meaning of the theory of obedience was tolerance forming through authoritarian behaviors. Raising children according to Domostroy was the sacred duty of parents. Interestingly, children who did not receive proper education behaved badly the fault lied with their parents. A minister of the church quotes a good saying of Domostroy,

So if children who are deprived of the instructions of their father and mother do amiss or do evil, then the father and mother with their children are sinful against God, and they fall into disgrace with people and become the mockery of people, evil to their house, but grief to themselves, shame and penalty from the judges (THE HOUSEHOLD BOOK, 2017). 
Coming to the consideration of the axiological aspects of traditional family education in the Belgorod region, we note that the family in the Belgorod province was patriarchal, preference was given to the eldest man. The established orders of everyday life were strictly observed and passed on from generation to generation. The householder enjoyed unlimited power, orders were taken from him without questions, and responsibilities were shared with allowance for gender and age. Families were not large, 7-8 people, but sometimes 14 or more people, divisions of the courtyard, land and property were inevitable. Parents mentioned in the will who they preferred to "live out their remaining days" with.

Family ties developed from the very family, as well as friendly ties of "copaternity and match-making" that arose in the process of living together. Common interests, mutual assistance between neighbors contributed to spiritual communication, joint celebration of holidays, exchange of information, further development of folk traditions.

The people of the Belgorod region are distinguished by kindness, which is inherent not only in older people. The region of Belgorod is a special land. Different cultures are comprehended in the geographical space of our region: Russian, Polish, Ukrainian, Lithuanian, Belarusian.

Emphasis is placed today on the need to create a favorable microclimate that contributes to the full development of healthy marital relations, spiritual and moral education of all family members.

In this regard, workers in the social and cultural sphere focus on the problems of family leisure, determine priority areas, highlight the most promising forms and methods, study interesting experiences in organizing leisure time.

The cultural institutions of the Belgorod Region have accumulated significant experience of working with families, and they hold interesting events. The most popular are Family quizzes "Happy Chance", competitive game programs "Mothers and Daughters", "Hello, Our Dads!", family gatherings "Let's sit side by side, let's talk amicably", evening stories "My Pedigree", "See into the Family Album", family panel games "Riding on the Wave of Cheeriness", family holidays "Family Where in Every Business There is a Creative "Self"”, evenings of rest, balls, holidays of family creativity, contests.

A popular form of work with families today is amateur associations and hobby clubs. Interestingly creative family clubs work in the Gubkinsky district, they are 36 in number today. This is a club for inferior family "Ochag” in the Miners' Palace of Culture, clubs of sports and recreations "Estapheta", "Yunost", "Zdorovie". 
Teachers, psychologists are invited to the classes of such clubs, questions of the psychology of relationships in families where "tough children" grow up are discussed.

The club of the young family "You and Me" in the Starotavolzhansky House of Culture unites more than forty married couples. Doctors, hairdressers, cooks, lawyers, and other specialists are invited to its meetings which take place 1-2 times a month.

Interestingly, the club "Family is Two I" works creatively in the Suvorov House of Culture. The club's program is highly topical and relevant - "The Inner World", "Raising Tough Children", “Marriage of Convenience”, "Divorce. How to Avoid of it?", "The Moral Climate of the Family" and others. These meeting, as a rule, are round-table tea-point talks. In the opinion of the very club members, such communications, exchange of views help spouses to get out of difficult situations with dignity, strengthens family relations.

In the Nikolsky House of Culture it has become a tradition to hold family evenings, competition programs "Come and Have Some Tea", "Home - Comfort and Warmth", "Whose Bride is Better" and others. A head of the farm, heads of sections, teachers, and rank-and-file collective farmers are invited to such events. The workers of the house of culture know how to get guests interested, to direct them to active participation in the evenings being held. They participate in contests of ditties, dancers, anecdotes and witty captions to drawings "What Does That Mean?". They enliven the evenings with lotteries and auctions selling souvenirs.

When working with families, many cultural institutions pay special attention to raising children and introducing them to folk traditions. And very instructive and interesting is the experience of the Kupen House of Folk Art which is the center of the revival of folk culture and the upbringing of children on folk traditions, the upbringing of family culture.

The center has developed a 34-hour program for studying family culture by schoolchildren. It embraces cultivation of love not only for their families but also for the native village, for their land, home, acquaints children with the spiritual foundations of the Russian patriarchal family. During children's activities in the study groups of folk crafts (pottery, carpentry, knitting, embroidery), teachers introduce children to the dynasties of rural craftsmen and crafts of the inhabitants of the villages of Kupino, Yablochkovo, Repnoye. They try to awaken a child's desire to create a beautiful thing in order to decorate their home (or school) with it, or to give it to someone from their family.

One of the priority areas of activity of cultural institutions of the region is the revival and development of family and household rituals based on the study of cultural heritage, folk traditions and customs of our region. 
At the Belgorod State Center of Folk Art, a center for the study of traditional culture has been created and has done well, the museum of folk culture has thrown its doors open to the public. A number of textbooks Folk Traditional Culture have been published. In addition to book manuals on traditional folk culture, specialists of the center have created educational videos about the rituals and holidays of the region.

In the district of Ivnyansk of the Belgorod region, the folklore and ethnographic expeditions are organized by the center of folk art to the villages of Dragunka, Peschanka, Kochetovka during which family and household traditions and rituals are explored - weddings, baptism, traditional Russian cuisine. The description of the rituals is included in the collection Springs under the Willows.

The work on the development of modern rituals and holidays is purposefully carried out by the Gubkin Organizational and Methodological Center. It has developed programs on Christianity for family clubs, scripts for a traditional wedding ceremony, and they regularly hold workshops: "Traditional Holidays and Ceremonies", "Introduction of the Rite of Naming", "Features of Family and the Household Traditions of the Gubkinskaya Territory". In the region a competition for the best scenario of a wedding ceremony, a rite of naming, coming of age, gold and silver weddings was held. In the village of Vislaya Dubrava a demonstration event " $\mathrm{A}$ Wedding Ceremony with Elements of an Old Gubkin Wedding” took place.

At present, the region has gained some experience in introducing elements of the traditional culture of the Belgorod region into family and household rituals. In several areas, modern weddings are held using old family and household traditions. These are in Krasnensky, Alekseevsky, Krasnogvardeisky, Novooskolsky, Borisovsky, Prokhorovsky and other districts of the region. So, for example, in the Valuisky district, the work on the revival and introduction of rituals of dignity by folklore groups of the bride and groom during the solemn registration of the newlyweds is in progress.

The times of change that our society has entered have led to dramatic changes not only in the field of social policy, economics, culture, but also in value orientations. The problem of moral stand of an individual, their responsibility for the fate and future of their Fatherland is more urgent than ever. Russian society needs not only undelayable reforms, but also spiritual self-perfecting.

Of great importance in the development of a modern personality is the use of all the wealth of folk wisdom which incorporates priceless ideas of training and education. Family and household traditions serve as a source for the development of humanistic culture of an individual. The experience of the present shows that being neglectful of the traditions of one's 
people, its past and present means the collapse in the established chains between generations and does irreparable damage to the moral formation of an individual. Bringing back to spiritual sources, reviving folk traditions and attracting their positive potential for solving pressing issues in the field of culture and spirituality is an integral part of the problem of national culture formation and national restoration. In our opinion, folk traditions are unclaimed spiritual and moral capital and experience of previous generations today. A person who does not realize the past, being confronted with the need to redefine their place in the world, a person being deprived of the historical experience of their people and other peoples, finds themselves outside the historical perspective and is able to live only today.

Consequently, spiritual rebirth is unthinkable without back to the origins, without restoration and imaginative interpretation of forgotten traditions and customs. Forgetting their roots, breaking the connection between times and generations, a person loses not only that which forms their national appearance, but also the connection with common human culture.

In our opinion, folk traditions have untapped educational opportunities. Therefore, it is necessary to form the culture of future family life in accordance with the traditions of native people, their spiritual and ethical culture. It is important to help a family consolidate its healthy spiritual foundations which undoubtedly have national traditions.

\section{REFERENCES}

CHECHETIN, V. V. Patriotic Family Education.1988. 210 p.

DAHL, V. I. Explanatory Dictionary of the Live Great Russian Language: In 4 Volumes. Reprography of the Edition. 1912-1914. Moscow: Tsytadel, 1998.

DYACHENKO, G. Full Church Slavonic Dictionary. Moscow, 1993. 184 p.

GAVROV, S. N. Historical Changes in the Institutes of Family and Marriage. Manual. Moscow: RDE MSTU, 2009. 134 p.

ILYIN, I. A. On Upbringing and Education in Future Russia. SPB, 2000. 462 p.

KALASHNIKOVA A. Information on Rebirth and Development of Modern Common Family Rites. Belgorod: BGCNT, 2003. 78 p.

MALTSEV, A. P. About the Role of Family and Society. Moscow, 1999. 78 p.

NEKRYLOVA, A. F.; SOKOLOVA, L. V. Upbringing of a Child in Russian Traditions. Moscow: The Iris Press, 2003. 196 p. 
THE HOUSEHOLD BOOK: How to Order a Domestic Life Agreeable to God and One's Own Life Inviolately. Moscow: DAR, 2017. 160 p.

USHINSKY, K. D. Anthropology of Education: Man as an Object of Education. In:

Experience of Educational Anthropology. Moscow: The URAO Press, 2002. p. 1-2.

VOLODINA, L. O. Moral and Spiritual Values of Education in Russian Family: The Problem of Meaning. Pedagogy in School, n. 2, p.13-28, 2000.

ZENKOVSKY, V. V. The Problems of Education in the Light of Christian

Anthropology. Moscow: The Svyato-Vladimir Bratstvo Press, 1993. 222 p.

\section{How to reference this article}

KURGANSKY, S. I.; BARANICHENKO, N. V.; BOVKUNOVA, U. V.; KISTENEV, V. V. Axiological aspects of traditional family education in the Belgorod region. Revista on line de Política e Gestão Educacional, Araraquara, v. 25, n. esp. 7, p. 3904-3913, Dec. 2021. eISSN:1519-9029. DOI: https://doi.org/10.22633/rpge.v25iesp.7.16147

Submitted: $13 / 03 / 2021$

Required revisions: 26/07/2021

Approved: 28/11/2021

Published: $31 / 12 / 2021$

Processamento e edição: Editora Ibero-Americana de Educação.

Correction, formatting, normalization and translation.

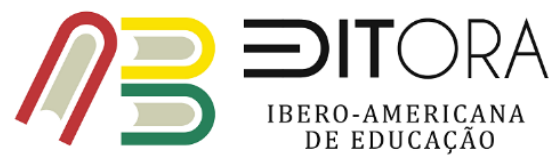

